УДК 338.48-6:7/8

\title{
- ПОНЯТТЯ КУЛЬТУРНОГО ТУРИЗМУ ТА ЙОГО КЛАСИФІКАЦІЇ
}

\author{
- Шевелюк Михайло Михайлович \\ - Аспірант, \\ ORCID: 0000-0001-6178-6455, e-mail: sheweluck.mih@gmail.com, \\ Київський національний університет культури і мистецтв, \\ вул. Є. Коновальця, 36, Київ, Україна, 01133
}

\section{- Для цитування:}

Шевелюк, М.М. (2020). Поняття культурного туризму та його класифікації. Питання культурології, (36), 99-109. doi: https://doi.org/10.31866/2410-1311.36.2020.221051.

\section{Анотація}

Мета статті - проаналізувати наявні визначення поняття «культурний туризм» та його класифікації. Методологія дослідження ґрунтується на застосуванні теоретичних методів гуманітарних досліджень. Наукова новизна полягає у культурологічному аналізі наявних визначень поняття «культурний туризм» та характеристиці особливостей класифікації. Висновки. Звернено увагу на труднощі у визначенні поняття «культурний туризм», пов'язані з необхідністю початкового аналізу похідних понять: «культура» і «туризм». Попри поширене розуміння культури як сукупності матеріальних і духовних цінностей, накопичених суспільством на певному етапі його розвитку, а також діяльності з їх створення, освоєння, збереження і поширення, у контексті цього дослідження з усіх наявних визначень терміна «культура» запропоновано використовувати підхід, згідно з яким ії̈ можна розглядати як процес виробництва цінностей і як продукт, тобто самі цінності. Це дає обґрунтовані підстави розглядати туризм як форму освоєння культурних продуктів. Наголошено на відсутності єдиного загальноприйнятого визначення термінів «туризм» і «культурний туризм», а також класифікації останнього на офіційному рівні та в науковому середовищі. Підкреслено, що різноманітність тлумачень цих понять пов'язана з неможливістю уніфікувати формулювання багатогранного явища, при вивченні яких слід враховувати не лише різні контексти, що залежать від виконуваних туризмом / культурним туризмом функцій, а й специфіку дотичних до туризму галузей і сфер діяльності. Зроблено висновок, що у понятті культурного туризму необхідна вказівка на мотивацію туристів як невід'ємну частину культурного туризму. За критерієм цілей поїздки запропоновано виокремлювати види культурного туризму (історичний, релігійний, подієвий, екологічний, етнокультурний, розважальний). Підкреслено, що виокремлення інших критеріїв класифікації вимагає подальшого дослідження і детального обґрунтування, що дасть можливість відобразити широту і багатогранний характер поняття «культурний туризм», його суть і масштабність.

Ключові слова: туризм; культурний туризм; культура; туристська діяльність; турист 


\section{- Вступ}

Культурний туризм із середини XX ст. перебуває в центрі пильної уваги українських і закордонних дослідників, проте до цього часу $є$ чимало труднощів не лише в чіткому його визначенні, а й у з'ясуванні його сутності, відмінних ознак і видів. Так, ряд спроб визначити поняття «культурний туризм» зводиться лише до споживання туристами «культурного продукту», що ставить цілий ряд питань, залишених без відповіді. Наприклад, що розуміти під «культурним продуктом», які види культури слід розглядати та ін. Пропоновані визначення часто $€$ схожими і різняться лише незначними нюансами, які не завжди відображають зміст поняття.

У цій ситуації логічним видається підхід, при якому спочатку визначаються самі поняття «туризм» і «культура», а потім, шляхом їх зіставлення, фрормується безпосередньо поняття культурного туризму. Це дасть обґрунтовані підстави для визначення самого поняття i, що важливіше - з'ясування його функціональної специфіки, що необхідно для чіткого вирішення дослідницьких завдань із проблематики культурного туризму.

Питання сутності туризму, зокрема й культурного туризму перебуває у полі зору українських і закордонних дослідників не одне десятиліття. Одне з перших визначень туризму сформулювали ще у 1942 р. швейцарські економісти і дослідники туризму В. Хунцикер та К. Крапф у своїй праці «Нариси загальної теорії туризму», яка аж до середини 90-х років XX ст. слугувала основою при підготовці кадрів і здійсненні спеціальних досліджень. Саме їхнє визначення туризму було взято за основу профільними міжнародними організаціями, а результати їхніх туризмознавчих досліджень стали теоретичним підґрунтям для функціонування сфери туризму, оскільки давали найбільш повне уявлення про сутність туризму, його види та роль у розвитку країни.

3 активним розвитком сфери туризму почали активно здійснюватися й дослідження цього явища культури. Так, у працях українських і закордонних дослідників вивчається світовий досвід організації туризму, види і принципи функціонування підприємств сфери туризму, розглядаються питання державної туристичної політики та ін. Зазначена проблематика висвітлюється у наукових розвідках таких вчених, як М. Бондаренко (2012), В. Герасименко (2013), М. Колосінська (2011), Д. Соловйов (2011) та ін. Вивченням туризму як економічного явища займаються М. Мальська, В. Худо, В. Цибух (2004) та ін. Безпосередньо культурному туризму присвячені праці О. Гнаткович й С. Назарової (2018), С. Дичковського (2019) та ін. Разом із тим, багато питань функціонування туризму, зокрема культурного, залишаються недостатньо висвітленими, що і зумовило вибір теми статті та її мету.

\section{- Мета статті}

Відсутність єдиного визначення поняття «культурний туризм» зумовила проблеми зі створенням єдиної, загальноприйнятої класифікації туризму як культурного явища. Уніфікованої і загальноприйнятої класифікації видів культурного туризму, втім, як і багатьох інших видів туризму, дотепер немає. Однак дослідниками робляться такі спроби. Мета нашого дослідження - проаналізувати на- 
явні визначення поняття «культурний туризм» та його класифікації. Методологія ґрунтується на застосуванні теоретичних методів гуманітарних досліджень. Наукова новизна полягає у культурологічному аналізі наявних визначень поняття «культурний туризм» та характеристиці особливостей класифікації.

\section{- Виклад матеріалу дослідження}

Говорячи про культуру, під цим поняттям заведено розуміти сукупність матеріальних і духовних цінностей, накопичених суспільством на певному етапі його розвитку, а також діяльність з їх створення, освоєння, збереження і поширення. У контексті цього дослідження з усіх наявних визначень терміна «культура» доцільно виокремити підхід, згідно з яким її можна розглядати ніби з двох сторін: як процес виробництва цінностей і як продукт, тобто самі цінності. Культура як продукт - це результат діяльності однієї людини або групи людей, що відображає рівень володіння ними тими нормами і технологіями діяльності, які приписує їм культура, а також уявлень про ті фрорми продукції, які дозволені їх культурою (Флиер, 1998, с. 337). Подібний погляд на культуру дає можливість ввести і поняття туризму як форми освоєння культурних продуктів. Проте, туризм тривалий час розглядався лише як переміщення і тимчасове перебування людей поза постійним місцем проживання. I лише в середині $X X$ ст. із значним збільшенням туристичних потоків та їхнім очевидним впливом на соціокультурну сферу назріла необхідність ширшого його визначення. Однак, ані на офіційному рівні, ані в науковому середовищі єдиного загальноприйнятого визначення не запропоновано й досі.

Так, Всесвітня туристська організація (UNWTO, англ. United Nations World Tourism Organization (https://www.unwto.org)) зазначає, що за своєю суттю туризм - це досвід, що включає куштування на смак місцевої їжі, ознайомлення з місцевими пейзажами і пам'ятками історичного значення. Міжнародна академія туризму (Academie Internationale du Tourisme, AIT, Монако (https://uia.org/s/ or/en/1100038736)) розглядає туризм як «загальне поняття для всіх фрорм тимчасового виїзду людей з місця постійного проживання з оздоровчою метою, для задоволення пізнавальних інтересів у вільний час або з професійно-діловою метою без здійснення оплачуваної діяльності в місці тимчасового перебування»; Міжнародна асоціація наукових експертів з туризму (AIECT) (International Association of Scientific Experts in Tourism (https://www.aiest.org/home/)) - як «сукупність відносин і явищ, що виникають під час переміщення і перебування людей у місцях, відмінних від їх постійного місця проживання і роботи»; $\mathrm{OOH}$ (https://www.un.org/ru/) - як «активний відпочинок, що впливає на зміцнення здоров'я, фрізичний розвиток людини, пов'язаний із пересуванням за межами постійного місця проживання». Закон України «Про туризм» від 15.09.1995 року № 324/95-ВР визначає це поняття як «тимчасовий виїзд особи з місця проживання в оздоровчих, пізнавальних, професійно-ділових чи інших цілях без здійснення оплачуваної діяльності в місці, куди особа від”їжджає» (Верховна Рада України, 1995).

В науковому середовищі туризм або ототожнюють із туристичним туром, тобто з діяльністю туроператорів і турагентів (Кабушкин, 2002), або розглядають 
його як «вид рекреації, пов'язаний із виїздом за межі постійного місця проживання, активний відпочинок, під час якого відновлення працездатності поєднується з оздоровчими, пізнавальними, спортивними і культурно-розважальними цілями» (Мальська та ін., 2004, с. 21). При цьому дослідники підкреслюють, що «туризму насамперед належить обов'язковість переміщення людини за межі місця свого постійного проживання» (Краснова \& Антонова, 2014, с. 134).

Така різноманітність тлумачень туризму пов'язана з неможливістю уніфікувати формулювання багатогранного поняття, в яке слід включити не лише різні контексти, що залежать від виконуваних туризмом функцій, а й врахувати специсіку дотичних до туризму галузей і сфер діяльності: починаючи від рекламноінфрормаційних послуг, транспорту, будівництва, сільського господарства, переробних галузей, і закінчуючи такими сферами діяльності, як освіта, охорона здоров'я, спорт і культура.

Стосовно поняття «культурний туризм», що складається з двох понять, які мають чимало визначень, також немає одностайності. ЮНЕСКО розглядає культурний туризм як відмінний від інших вид туризму, що «враховує культури інших народів». Хартія з культурного туризму Міжнародної ради з питань пам'яток і визначних місць (англ. International Council of Monuments and Sites, ICOMOS) визначає культурний туризм як форму туризму, основною метою якого, крім інших цілей, $є$ «відкриття пам'яток та об'єктів». ICOMOS характеризує культурний туризм як «невеликий сегмент ринку, ретельно організований, пізнавальний або освітній і часто елітарного характеру, присвячений представленню і роз'ясненню культурної ідеї» (International Council on Monuments and Sites, 1999).

Керівник групи з вивчення культурного туризму АТЛАС (ATLAS, англ. Association for Tourism and Leisure Education) Г. Річардс розуміє під культурним туризмом «споживання туристами мистецтва, художньої спадщини, фольклору та цілого ряду інших проявів культури» (Richards, 1996). Філософ і мистецтвознавець О. Генісаретський - масовий вид відновлювальної, дозвіллєвої та розвиваючої активність населення діяльності, що має давнє коріння в історії паломництв і подорожей, в розвитку туристично-екскурсійного руху. Зобов'язаний своїм сучасним розмахом поширенню досягнень НTP на всю соціально-культурну сферу суспільства, підвищенню загальної соціальної мобільності урбанізованого населення, і виникненню в рамках сучасного способу життя нового класу потреб, названих культурно-історичними або культурноекологічними (Генисаретский, 1987). В. Черненко і Т. Колпащикова (2012) визначають культурний туризм як комплексне явище, в якому поєднується «виїзд туриста з території свого регіону (країни) в інший регіон (країну) для ознайомлення з культурою та її розуміння, в результаті чого особистість формує культурну компетентність, самосвідомість і культурне самовизначення в світовому просторі». Крім того, одні сучасні дослідники вважають, що культурний туризм - це вид туризму, метою якого є ознайомлення з історією, культурою, звичаями, духовними і релігійними цінностями певної країни (Квартальнов, 2001). Інші визначають культурний туризм як процес ознайомлення з «чужою» культурою й осмислення цієї культури, в результаті чого відбувається розширення пізнавальних інтересів особистості щодо історико-культурних традицій, 
звичаїв, проявів матеріальної культури інших народів, націй і національностей (Красная, 2006).

Серед українських дослідників туризм розглядається як мобільна форма споживання і рекреаційної діяльності, що ґрунтується на доланні простору, та пов'язана з територією, характером середовища (не лише природного, а й соціально-культурного та економічного середовища людської діяльності) (Любіцева, 2005, с. 13). В. Кифяк (2015) окреслює туризм як «вид економічної діяльності, пов'язаний з обслуговуванням людей, які тимчасово перебувають поза місцем постійного проживання» (с. 69). На його думку, «туристичні підприємства та інші суб'єкти туристичної діяльності працюють на комерційних засадах, створюючи при цьому валову додану вартість шляхом виробництва, просування та реалізації туристичних продуктів, спрямованих на задоволення потреб споживачів» (с. 69-70).

Отож, як і поняття «туризм», поняття «культурний туризм» має чимало визначень, що пов'язано з широтою і складністю цього явища. Разом із тим, аналіз наведених визначень дає підстави зробити висновок, що поняття «культурний туризм» може містити в собі ознаки й інших видів туризму, якщо акцент ставиться саме на його культурологічній стороні. Однак тут важливим аспектом $€$ саме розставлення пріоритетів особи, яка подорожує, в зв'язку з чим необхідно приділяти особливу увагу мотивації туристів. Найбільш вдалим і влучним визначенням культурного туризму є думка С. Красної (2006), що дає підстави вважати кінцевим підсумком останнього сформованість культурної компетентності туристів.

Відсутність єдиного визначення поняття «культурний туризм» зумовила й проблеми зі створенням єдиної, загальноприйнятої класифікації туризму як культурного явища. Уніфікованої і загальноприйнятої класифікації видів культурного туризму, втім, як і багатьох інших видів туризму, на сьогодні немає. Проте дослідниками робляться такі спроби. Приміром, заслуговує на увагу класифікація, в якій загалом відображено особливості цього виду туризму завдяки його поділу на такі види: 1) культурно-історична спадщина: історичні території, пам'ятки архітектури, зони археологічних розкопок, музеї різної тематики, народні промисли, національні свята, обряди і традиції, фольклорні колективи; 2) актуальна культура: сучасне мистецтво, спосіб життя населення, національна кухня, костюми тощо (Красная, 2006).

Згідно з іншою класифікацією, види культурного туризму згруповано у такі чотири групи: історичні подорожі; географічні подорожі; культурологічні подорожі; екологічний туризм (Драгичевич-Шешич \& Стойкович, 2012). У цій класифікації подорожі поділені залежно від цілей поїздки, однак такий поділ не відображає повною мірою особливостей розвитку культурного туризму на сучасному етапі. Крім того, одна і та сама подорож може бути віднесена одразу до кількох категорій, що ускладнює класифрікацію.

О. Мошняга (2008) виокремлює такі види культурного туризму: 1) культурноісторичний (відвідування історичних місць і пам'яток, участь у тематичних лекціях); 2) культурно-подієвий (відвідування культурних заходів, свят, фестивалів); 3) культурно-релігійний (відвідування святинь, релігійних місць, ознайомлення 
з релігією і звичаями певної країни); 4) культурно-археологічний (відвідування археологічних розкопок, участь в археологічних експедиціях); 5) культурноетнографічний (відвідування з метою вивчення культури, побуту, мови і фольклору країн); 6) культурно-етнічний (ознайомлення із культурним надбанням свого народу); 7) культурно-антропологічний (відвідування з метою ознайомлення із сучасною культурою, місцевими жителями, їх традиціями і звичаями); 8) культурно-екологічний (інтерес до особливостей взаємодії природи і культури, участь в екологічних програмах). Поза сумнівами, ця класифікація є повною і деталізованою, проте ґрунтується вона на одному критерії - цілі відвідування, що не може відобразити все різноманіття культурного туризму.

Відповідно до іншої класифікації, види культурного туризму доцільно виокремити за критерієм діяльності культурного туриста: 1) відвідування архітектурних пам'яток, музеїв та інших визначних пам'яток; 2) відвідування культурних заходів і свят; 3) відвідування лекцій, семінарів, курсів іноземних мов з метою збагачення культурного досвіду; 4) участь у фольклорній діяльності (Лойко, 2007). Ця класифрікація має цінність з точки зору виокремлення різноманітності діяльності туристів і представлення культурного туриста як активного учасника туристичного процесу. Водночас сумнівним видається чіткість поділу культурного туризму за такими критеріями, оскільки багато видів культурного туризму виходять взаємопов'язаними.

Згаданий вище Г. Річардс у своїх працях поділяє культурний туризм на такі сегменти: 1) освітній туризм; 2) релігійний туризм; 3) відвідування родичів і друзів; 4) гастрономічний туризм; 5) креативний туризм; 6) туризм з метою волонтерства; 7) лікувально-оздоровчий / SPA i wellness-туризм; 8) туризм з метою вивчення мови; 9) духовний і холістичний туризм (Richards, 1996).

Таким чином, як свідчить здійснений аналіз наукової літератури, до невирішених належать питання, що стосуються визначення поняття «культурний туризм» і його класифікації. Наявні ж класифрікації характеризуються або недостатньою систематизацією об'єктів культурного туризму, або обмеженим вибором критеріїв для класифрікування, або види культурного туризму є взаємопроникними, що ускладнює розуміння поділу культурного туризму на види. Виходячи з наведених класифікацій, до видів культурного туризму, виокремлених за критерієм цілей поїздки, слід віднести: історичний; релігійний, подієвий; екологічний; етнокультурний; розважальний. Виокремлення інших критеріїв класифікації вимагає подальшого дослідження і детального обґрунтування, що дасть можливість відобразити широту і багатогранний характер поняття «культурний туризм», його суть і масштабність. У самому ж понятті культурного туризму необхідна вказівка на мотивацію туристів як невід'ємну частину культурного туризму. У загальних рисах культурний туризм передбачає відвідування представником однієї культури території іншої, осягнення її духовних і матеріальних цінностей, у результаті чого турист виробляє своє «бачення» іншого і на цій основі розвиває, розширює коло своєї культурної ерудиції.

\section{- Висновки}

Сьогодні туризм стає сполучною ланкою між народами, країнами і континентами, інструментом активного пізнання світу, спілкування і зміцнення дружби між 
людьми, засобом виховання любові до рідної землі і здорового способу життя. Серед особливостей, що визначають мотивації туризму: відпочинок й оздоровлення; культура і гостинність; подорожі; інтерес до нових знань; дослідження культур та ін. Культурний туризм охоплює всі аспекти подорожі, за допомогою якої людина дізнається про життя, культуру, звичаї іншого народу. Туризм, таким чином, є важливим засобом створення культурних зв'язків і міжнародної співпраці.

Разом із тим, в останні роки в культурному туризмі відбуваються досить швидкі зміни і перетворення, пов'язані з новими його формами, які можуть більш активно розвиватися в майбутньому. До них відносять форми культурного споживання, обумовлені новими технологіями, а також зростання незалежності культурного туриста, яка дає можливість досліджувати нові напрямки, не лише віддалені та екзотичні, а й повторно відкривати вже відомі. Завдяки новим технологіям культурний туризм розвиватиметься по-новому: не як вузька туристична ніша, а стане загальним засобом споживання елементів повсякденного життя, нового досвіду, інтегрованого в місцеві соціальні, економічні та культурні системи. Це вносить свої корективи не лише в його сутність і призначення, а й розробку його теоретичних засад, зокрема класифікації його видів, що вимагає подальшого вдосконалення.

\section{- Список використаних джерел}

Бондаренко, М. П. (2012). Теретичні засади розвитку індустрії туризму. Економічний часопис XXI, 3-4, 19-22.

Генисаретский, О., \& Подунова, И. (1987). Досуг и творчество в культурном туризме. Государственная библиотека СССР им. Ленина.

Герасименко, В. Г. (2013). Ринки туристичних послуг: стан і тенденції розвитку. [Монографія]. Астропринт.

Гнаткович, О. Д., \& Назарова, С. В. (2018). Сучасні тенденції розвитку культурного туризму. В Наукова думка сучасності і майбутнього, Матеріали 23 Всеукраїнської практично-пізнавальної конференції (с. 24-26). Дніпро, 25-31 жовтня 2018 р. Наукове мислення.

Дичковський, С. (2019). Культурний туризм як сфера реалізації дозвіллєвих технологій та віртуального досвіду. Вісник Національної академії керівних кадрів культури і мистецтв, 3, 89-95.

Драгичевич-Шешич, М., \& Стойкович, Б. (2012). Культура: менеджмент, анимация, маркетинг. Тигра.

Верховна Рада України. (1995). Про туризм. Закон України від 15.09.1995 р., № 324/95BP. http://zakon4.rada.gov.ua/laws/show/324/95-\%D0\%B2\%D1\%80.

Кабушкин, Н. И. (2002). Менеджмент туризма. Новое знание.

Квартальнов, В.А. (2001). Туристика. Советский спорт.

Кифяк, В. Ф. (2015). Розвиток туризму як один зі сценаріїв покращення соціальноекономічного стану Чернівецької області. Вісник Чернівецького торговельноекономічного інституту КНТЕУ, 2(58), 67-81.

Колосінська, М.І. (2011). Дослідження теоретичних підходів до визначення категорії "туризм". Економіка. Управління. Інновації. Серія: Економічні науки, 2. http://nbuv.gov.ua/j-pdf/eui_2011_2_22.pdf. 
Красная, С. А. (2006). Культурный туризм: просветительская сущность и фракторы развития [Авторефрерат диссертации кандидата культурологии, Московский государственный университет культуры и искусств].

Краснова, Ю.А., \& Антонова, А. В. (2014). Поняття та юридичні ознаки туризму в Україні. Науковий вісник Національного університету біоресурсів і природокористування України, 197(3), 132-140.

Лойко, О. Т. (2007). Туризм и гостиничное хозяйство. Издательство Томского политехнического университета.

Любіцева, О. О. (2005). Ринок туристичних послуг. Альтерпрес.

Мальська, М. П., Худо, В. В., \& Цибух, В. І. (2004). Основи туристичного бізнесу. Центр навчальної літератури.

Мошняга, Е.В. (2008). Концептуальное пространство межкультурной коммуникации в туризме. Вестник Московского государственног университета. Серия 18: Социология и политология, 4, 5-19.

Соловйов, Д.І. (2011). Вдосконалення понятійного апарату теоретичного забезпечення функціонування туристичної сфери. Вісник Бердянського університету менеджменту і бізнесу, 4(16), 82-88.

Флиер, А. Я. (1998). Культура. В Культурология XX век (с. 337). Университетская книга.

Черненко, В. А., \& Колпащикова, Т. Ю. (2012). Развитие культурно-познавательного туризма в Северо-Западном федеральном округе Российской Федерации. Издательство СПбГУСЭ.

International Council on Monuments and Sites. (1999). International Cultural Tourism Charter. file:///C:/Users/STESHE 1/AppData/Local/Temp/ICOMOS\%20International\%20 Cultural\%20Tourism\%20Charter\%201999.pdf.

Richards, G. (Ed.). (1996). Cultural Tourism in Europe. ATLAS. http://www.tram-research.com/ cultural\%20tourism\%20in\%20europe.PDF.

\section{- References}

Bondarenko, M. P. (2012). Teretychni zasady rozvytku industrii turyzmu [Theoretical foundations of the tourism industry]. Economic Journal XXI, 3-4, 19-22 [in Ukrainian].

Chernenko, V. A., \& Kolpashchikova, T. Yu. (2012). Razvitie kul'turno-poznavatel'nogo turizma $\checkmark$ Severo-Zapadnom federal'nom okruge Rossiiskoi Federatsii [Development of cultural and educational tourism in the North-West Federal District of the Russian Federation]. Izdatel'stvo SPbGUSE [in Russian].

Dragicevic-Sesic, M., \& Stojkovic, B. (2012). Kul'tura: menedzhment, animatsiya, marketing [Culture: management, animation, marketing]. Tigra [in Russian].

Dychkovskyi, S. (2019). Kulturnyi turyzm yak sfera realizatsii dozvillievykh tekhnolohii ta virtualnoho dosvidu [Cultural tourism as a sphere of realization of leisure technologies and virtual experience]. Bulletin of the National Academy of Management of Culture and Arts, 3, 89-95 [in Ukrainian].

Flier, A. Ya. (1998). Kul'tura [Culture]. In Kul'turologiya XX vek [Cultural studies of the $20^{\text {th }}$ century] (p. 337). Universitetskaya kniga [in Russian].

Genisaretskii, O., \& Podunova, I. (1987). Dosug i tvorchestvo v kul'turnom turizme [Leisure and creativity in cultural tourism]. Gosudarstvennaya biblioteka SSSR im. Lenina [in Russian]. 
Gerasimenko, V. G. (2013). Rynky turystychnykh posluh: stan i tendentsii rozvytku [Markets of tourist services: the state and trends of development] [Monograph]. Astroprint [in Ukrainian].

Hnatkovych, O. D., \& Nazarova, S. V. (2018). Suchasni tendentsii rozvytku kulturnoho turyzmu [Modern tendencies of development of cultural tourism]. In Naukova dumka suchasnosti i maibutnoho [Scientific thought of the present and the future], Proceedings of the $23^{\text {rd }}$ All-Ukrainian Practical and Cognitive Conference (pp. 24-26). Dnipro, October 25-31, 2018. Naukove myslennia [in Ukrainian].

International Council on Monuments and Sites. (1999). International Cultural Tourism Charter. file:///C:/Users/STESHE 1/AppData/Local/Temp/ICOMOS\%20International\%20 Cultural\%20Tourism\%20Charter\%201999.pdf [in English].

Kabushkin, N. I. (2002). Menedzhment turizma [Tourism Management]. Novoe Znanie [in Russian].

Kolosinska, M. I. (2011). Doslidzhennia teoretychnykh pidkhodiv do vyznachennia katehorii "turyzm" [Research of theoretical approaches to determining the category of "tourism"]. Economics. Management. Innovations. Series: Economic Sciences, 2. http://nbuv.gov.ua/j-pdf/eui_2011_2_22.pdf [in Ukrainian].

Krasnaya, S. A. (2006). Kul'turnyi turizm: prosvetitel'skaya sushchnost' i faktory razvitiya [Cultural tourism: educational essence and development factors] [Abstract of PhD Thesis, Moskovskii gosudarstvennyi universitet kul'tury i iskusstv] [in Russian].

Krasnova, Yu. A., \& Antonova, A. V. (2014). Poniattia ta yurydychni oznaky turyzmu v Ukraini [Understanding and legal signs of tourism in Ukraine]. Science Bulletin of the National University of Bioresources and Natural History of Ukraine, 197(3), 132-140 [in Ukrainian].

Kvartal'nov, V. A. (2001). Turistika [Tourism]. Sovetskii sport [in Russian].

Kyfiak, V. F. (2015). Rozvytok turyzmu yak odyn zi stsenariiv pokrashchennia sotsialnoekonomichnoho stanu Chernivetskoi oblasti [Development of tourism as one of the scenarios for improving the socio-economic condition of Chernivtsi region]. Bulletin of the Chernivtsi Trade and Economic Institute KNTEU, 2(58), 67-81 [in Ukrainian].

Liubitseva, O. O. (2005). Rynok turystychnykh posluh [Rinoks of tourist services]. Alterpres [in Ukrainian].

Loiko, O. T. (2007). Turizm i gostinichnoe khozyaistvo [Tourism and hotel industry]. Izdatel'stvo Tomskogo politekhnicheskogo universiteta [in Russian].

Malska, M. P., Khudo, V. V., \& Tsybukh, V. I. (2004). Osnovy turystychnoho biznesu [The basics of tourist business]. Tsentr navchalnoi literatury [in Ukrainian].

Moshnyaga, E. V. (2008). Kontseptual'noe prostranstvo mezhkul'turnoi kommunikatsii $v$ turizme [Conceptual space of intercultural communication in tourism]. Vestnik Moskovskogo gosudarstvennog universiteta. Seriya 18: Sotsiologiya i politologiya, 4, 5-19 [in Russian].

Richards, G. (Ed.). (1996). Cultural Tourism in Europe. ATLAS. http://www.tram-research.com/ cultural\%20tourism\%20in\%20europe.PDF [in English].

Soloviov, D. I. (2011). Vdoskonalennia poniatiinoho aparatu teoretychnoho zabezpechennia funktsionuvannia turystychnoi sfery [In full understanding of the theoretical safety of the apparatus of the tourist sphere]. Bulletin of the Berdyansk University for Management and Business, 4(16), 82-88 [in Ukrainian]. 
Verkhovna Rada of Ukraine. (1995). Pro turyzm [On Tourism]. Law of Ukraine of 15.09.1995, № 324 / 95-VR. http://zakon4.rada.gov.ua/laws/show/324/95-\%D0\%B2\%D1\%80 [in Ukrainian].

\section{- THE CONCEPT OF CULTURAL TOURISM AND ITS CLASSIFICATION}

\section{- Mykhailo Sheveliuk}

PhD student, ORCID: 0000-0001-6178-6455, e-mail: sheweluck.mih@gmail.com, Kyiv National University of Culture and Arts, Kyiv, Ukraine

\section{- Abstract}

The purpose of the article is to analyse the existing definitions of the concept of "cultural tourism" and its classification. The research methodology is based on the application of theoretical methods of humanitarian research. The scientific novelty of the study is generally related to the cultural analysis of the existing definitions of "cultural tourism" and its classifications. Conclusions. Attention is drawn to the difficulties in defining the concept of "cultural tourism", associated with the need for an initial analysis of derivative concepts: "culture" and "tourism". Despite the widespread understanding of culture as a set of material and spiritual values accumulated by society at a certain stage of its development, as well as activities for their creation, development, preservation and dissemination, in the context of this study of all available definitions of "culture" with which it can be considered as a process of production of values. This gives reasonable grounds to consider tourism as a form of development of cultural products. It emphasises that there is no single common definition of the terms "tourism" and "cultural tourism", as well as the classification of the latter at the official level and in the scientific community. It is emphasized that the diversity of interpretations of these concepts is due to the inability to unify the formulation of a multifaceted phenomenon, the study of which should take into account not only different contexts depending on the functions performed by tourism / cultural tourism, but also take into account specific industries and areas. It is concluded that the concept of cultural tourism requires an indication of the motivation of tourists as an integral part of cultural tourism. According to the criteria of the goals of the trip, it is proposed to distinguish the types of cultural tourism (historical; religious; event; ecological; ethnocultural; entertainment). It is emphasized that the selection of other classification criteria requires further study and detailed justification, which will reflect the breadth and multifaceted nature of the concept of "cultural tourism", its essence and scale.

Keywords: tourism; cultural tourism; culture; tourist activity; tourist 


\section{- ПОНЯТИЕ КУЛЬТУРНОГО ТУРИЗМА И ЕГО КЛАССИФИКАЦИИ}

\section{- Шевелюк Михаил Михайлович}

- Аспирант,

ORCID: 0000-0001-6178-6455, e-mail: sheweluck.mih@gmail.com, Киевский национальный университет культуры и искусств, Киев, Украина

\section{Аннотация}

Цель статьи - проанализировать существующие определения понятия «культурный туризм» и его классификации. Методология исследования основана на применении теоретических методов гуманитарных исследований. Научная новизна заключается в культурологическом анализе имеющихся определений понятия «культурный туризм» и характеристике особенностей классификации. Выводы. Обращено внимание на трудности в определении понятия «культурный туризм», связанные с необходимостью начального анализа производных понятий: «культура» и «туризм». Несмотря на распространенное понимание культуры как совокупности материальных и духовных ценностей, накопленных обществом на определенном этапе его развития, а также деятельности по их созданию, освоению, хранению и распространению, в контексте данного исследования из всех имеющихся определений термина «культура» предложено использовать подход, согласно с которым ее можно рассматривать как процесс производства ценностей и как продукт, то есть сами ценности. Это дает обоснованные основания рассматривать туризм как форму освоения культурных продуктов. Отмечено отсутствие единого общепринятого определения терминов «туризм» и «культурный туризм», а также классификации последнего на официальном уровне и в научной среде. Подчеркнуто, что разнообразие толкований этих понятий связано с невозможностью унифицировать формулировки многогранного явления, при изучении которого следует учитывать не только различные контексты, зависящие от выполняемых туризмом / культурным туризмом ффункций, но и учесть специфику касающихся туризма отраслей и сфер деятельности. Сделан вывод, что в понятии культурного туризма необходимо указание на мотивацию туристов как неотъемлемую часть культурного туризма. По критерию целей поездки предложено выделять виды культурного туризма (исторический; религиозный, событийный, экологический; этнокультурный; развлекательный). Подчеркнуто, что выделение других критериев классификации требует дальнейшего исследования и детального обоснования, что позволит отразить широту и многогранный характер понятия «культурный туризм», его суть и масштабность.

Ключевые слова: туризм; культурный туризм; культура; туристская деятельность; турист 